\title{
European island Outermost Regions and climate change adaptation: a new role for regional planning
}

\author{
Cecilia Ribalaygua \\ University of Cantabria, Spain \\ cecilia.ribalaygua@unican.es \\ Francisco García \\ University of Cantabria, Spain \\ franciscojose.garcia@unican.es (corresponding author) \\ Héctor García Sánchez \\ University of Las Palmas de Gran Canaria, Spain \\ hectorjulian.garcia@ulpgc.es
}

\begin{abstract}
Some European regions are experiencing unprecedented impacts due to climate change. The islands of the Outermost Regions are also being affected by this phenomenon. When these islands have a higher level of functional complexity, climate change increases the difficulty of defining their urban and regional planning tools. A comparative analysis of the characteristics of these islands (comparing land use and demographic density) and a review of the efficacy of planning tools for incorporating climate change adaptation has been developed in order to understand the transformations produced in the regulatory frameworks. Through the case studies of Gran Canaria (Spain) and Reunion Island (France), which show high levels of urban and peri-urban land use pressure, the paper focuses on analysing the degree of mainstreaming adaptation strategies, as key elements for land use planning in a context of climate change. Results show a dysfunction between adaptation needs and the incorporation of the climatic issue in land use management. Insular planning tools do not generally consider climate change adaptation and excessive top-down management is observed in the decisionmaking process. This paper contributes new case studies to the literature, comparing two non-sovereign European islands, and reviews the regulatory framework on adaptation in insular contexts related to climate change.
\end{abstract}

Keywords: climate change adaptation, Gran Canaria, islands, Outermost Regions, Reunion Island, spatial planning, urban planning

https://doi.org/10.24043/isj.78

(C) 2019-Institute of Island Studies, University of Prince Edward Island, Canada. 


\section{Introduction}

The increase in extreme events due to climate change is necessitating the reformulation of planning tools, focusing on mainstreaming adaptation into spatial and urban planning (Füssel, 2007; Mastrandrea et al., 2010; Nurse et al., 2014; While \& Whitehead, 2013). Although the concept of adaptation to climate change has a long history in the scientific literature, incorporation into planning tools is at a very early stage (Berrang-Ford et al., 2011; Tompkins et al., 2010). In this sense, several institutions are promoting the introduction of climate change adaptation into planning, such as the United Nations Urban Agenda and the $13^{\text {th }}$ Sustainable Development Goal (Climate Action); the European Union with the Covenant of Mayors promoting adaptation action plans; or the Inter-American Development Bank, developing specific methodologies for transforming into resilient cities and regions the Latin America and the Caribbean urban areas (IADB, 2016; UN-Habitat, 2014). There is a close relationship between adaptation strategies associated with climate change and the confluence of local vulnerability factors (Smit \& Wandel, 2006; Vogel et al., 2007). These relationships lead to what Etkin (2009) calls the chain of causes and effects, where climate change in conjunction with a lack of adequate planning tools favours the progression of risk and the concatenation of numerous hazards.

In the specific case of island territories, these variables compromise the resilience of their functional structures (Aswani, 2015; Lazrus, 2012). Some islands, as limited territories, are becoming places for experimentation on alternative planning tools in the face of climate change (Depraetere, 2008; Gagliardi, 2009, p. 47; Hernández et al., 2018) in combination with sustainable development (Chapman, 2011). Critical nodes on the world scale such as small islands (King, 2009, p. 77) are ideal places for comparative exploration of local-scale development strategies for their later projection at an international scale. In fact, as Depraetere (2008, p. 4) has suggested, islands can even become references in international environmental policies, whose experiences can be transferred to continental territories. In relation to climate change, islands play a decisive role, even being proposed in the "Islands Declaration on Climate Change" as "sentries of climate change" (Region Reunion, 2014). In this context, the special island conditions make the practice of urban and regional planning a sector of constant experimentation.

Our analysis in this paper regarding the phenomenon of climate change and the proposal of adaptation strategies within planning focuses on the islands of Europe's Outermost Regions (ORs) and whether new formulas related to territorial management can be extrapolated to the urban and spatial policies of the continent. The ORs are nine territories that, although geographically far from continental Europe, make up part of some of the European Union (EU) member states. In contrast to the countries and overseas territories, they are considered an integral part of the EU (Schengen Area). Except for French Guiana, the ORs are mainly made up of small islands and archipelagos (Azores, Madeira, Canarias, Saint-Martin [French Zone], Mayotte, Guadeloupe, Martinique, and Reunion Island). These territories share some common characteristics due to their functional and spatial complexity, their remote location with respect to the European continent $(>800 \mathrm{~km})$, their limited surface with extreme topography, and their economic dependence. The islands of the ORs have been immersed in a transitional period of spatial and urban planning for a few years (ESPON, 2013; Laissy, 2011). Alterations produced by climate change have a significant impact on ORs: extreme 
storm events with floods, increase in temperature, droughts, and especially sea-level rise (European Commission, 2009; Sauter et al., 2013) clearly affect the islands, whose economic development capacities are seriously threatened.

The islands of the outermost regions follow global dynamics of urban population growth. In the EU, approximately $73 \%$ of the total population lives in cities and adjacent neighbourhoods (European Commission, 2014a; European Union, 2011). Incremental urbanization has been a constant since the 1960s (European Union, 2014, p. 10; Julien, 2000), and this developmental period continues today (Nabielek et al., 2016).

The European urban policy in a period of changing climate is facing different realities within the territories of the Union. In the specific case of the islands in the ORs, the urban expansion is very similar to what happens in continental Europe, but in fragmented and small territories (ESPON, 2013). The spatial distribution of urban land use is generalized in a polycentric way, dominated by a reference centre and different poles of industrial and/or tourist activity. Depending on the degree of functional complexity, the urban fabric extends in these limited territories persistently. Thus, in recent years, the increase in urban inhabitants has in some islands led to surpassing the European average percentage, rising to $80 \%$ of the local population.

The demographic explosion that occurred in the second half of the 20th century, with the development of small and medium-sized cities, required the improvement of the socioeconomic conditions of these territories. This took place thanks to the EU Cohesion Policy that has allowed the investment in infrastructures of high productive value and poles of industrial activity (Gagliardi \& Percoco, 2017). This situation has promoted urban concentration, directing the economy towards the tertiary sector favoured by the attraction capacity as tourist destinations (ESPON, 2013; Solbes, 2011). Conversely, mass tourism has provoked the collapse of certain parts of the islands' natural environment like within other insular regions (Garcia \& Servera, 2003; Needham \& Szuster, 2011). Among the factors leading to a reduction in environmental quality, the following should be highlighted: urban expansion due to tourism (ESPON, 2013), as well as the building of second residences on the coast; coastal erosion; water shortages; wildfires; and risks of soil erosion. Climatic change, which is a global problem, also has a palpable impact on island territories (European Commission, 2009, 2014b; Solbes, 2011, UICN, 2010).

Land scarcity and the generally complex characteristics of insular territory heavily influence the development of planning tools, which could inspire continental spatial and urban policies (Depraetere, 2008). If, moreover, the islands from ORs are receptor poles for mass tourism, they become complex multifunctional activity centres that require the development of spatial planning that goes beyond the specification of land use and the planning of development, acquiring a supra-insular spatial consciousness integrating climate change strategies, as pointed out in the 2016 European Urban Agenda.

The Urban Agenda for the EU, raised in the Pact of Amsterdam (European Commission, 2016), is the starting point in the spatial reinterpretation of cities and their relationship with the environment. In this sense, the new European Urban Agenda includes the climate issue among its priority themes, and especially the management of adaptation to the future climate, in line with the EU Strategy on Adaptation (European Commission, 2013).

The insular systems are situated within a wide-ranging sustainability environment (Moncada et al., 2009), and can provide a unique opportunity to explore innovative focuses 
in generating solutions to the global spatial and urban problems (Hay, 2006, p. 21). The specific nature of the islands' cases and their role as a useful laboratory for developing suitable planning strategies to face the challenges of climate change are also reflected by other authors, such as Chapman (2011) or Lörincz (2011). Chapman (2011) developed a questionnaire for technicians with planning responsibilities in different island territories in order to establish the main challenges considered in the planning processes. Along with recurring issues related to land use management, heritage conservation, economic management and urban services, climate change and the environment was positioned as one of the main concerns. In this sense, the climate issue requires us to confront experimentally new urban and spatial planning in places that are especially complex and sensitive like the islands and archipelagos.

These concerns of island planners are also in line with the preoccupations highlighted in the communitarian policy, as reflected in the EU Strategy on Adaptation and the Pact of Amsterdam. The Outermost Regions, and especially their islands, are subordinated to the political decisions of the Union, but the local nature of the implications that climate change has in these territories obliges a local focus on spatial and urban planning tools. These tools, in process of experimentation, are now becoming a source of inspiration for planning strategies in the continent.

\section{Material and methods}

This study has been focussed on detecting those Outermost Islands with the greatest anthropogenic pressure in order to, once these are selected, verify the degree of integration of adaptation to climate change in their planning tools (mainstreaming) (Figure 1).

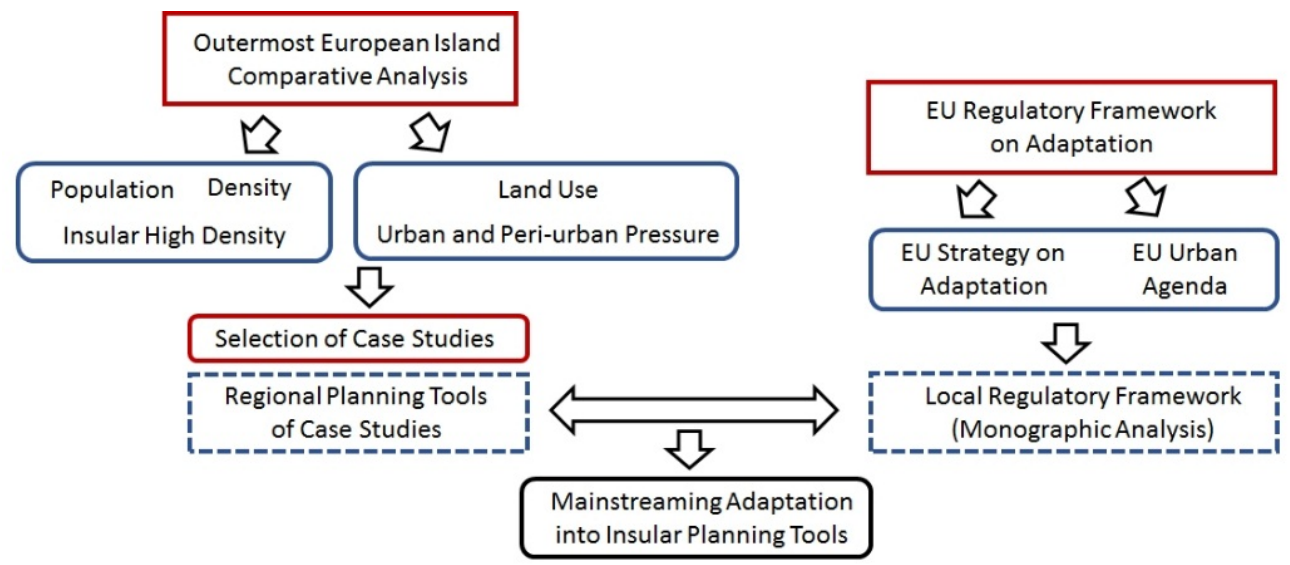

Figure 1: Scheme of research structure. Source: Compiled by authors.

Therefore, it is necessary to approach the analysis with a dual methodology: quantitative-comparative (among islands of different types and with other continental regions); and qualitative-monographic (comparing their planning criteria in relation to general aims). While the monographic studies of cases provide detailed definitions of the phenomenon and explanations of the characteristics of the relationships among the causes and effects, they do not permit the establishment of criteria that can be transferred to other situations. In contrast, comparative studies provide conclusions that can be applied to other cases, with adaptations to each situation and context (Hantrais, 2008; Booth, 2011). In the same sense, 
Svedin (2011) highlights the necessity of completing the comparative study with the description of cases.

As well as the typological classifications related to historical or socioeconomic factors such as those developed by Warrington \& Milne (2007), Sanguin (2007) identified five typologies within the European territorial context. The islands of the ORs are, according to Sanguin (2007), within the second typology (Category 2), characterized by the existence of several activity subcentres that generate complex multifunctional dynamics. These territories are characterized by a diversity of urban functions that are directly related to rural settings, with a reciprocal dynamism among the islands' subcentres. This is the situation of the Balearic Islands, the Canary Islands, Sardinia, Corsica, the Azores or the Greek Islands. The official capital of the island functions as the principal centre, while at the same time, other smaller cities provide services and economic activities (Sanguin, 2007).

The study focuses on determining the level of representativeness of these islands with great anthropogenic pressure, in relation to the rest of the European islands closer to the continent, and on detecting the level of response of spatial and urban planning tools. Comparative analysis enables the identification of differentiated territorial patterns depending on the degree of "isolation" of the islands categorized by Sanguin's second typology. With two basic reference parameters: the urban footprint (measured in percentage of land use based on specific mapping and digitalised measurements) and the density (measured in inhabitants $/ \mathrm{km}^{2}$ ), based on national statistical sources, we can determine which cases are the most representative in terms of anthropogenic footprint for a later monographic review.

The identified types of land use are grouped into three categories. Urban land use corresponds to areas that through urbanisation processes have acquired the condition of urban; this kind of land use consists of the spaces where population settlements cohabit with intensive secondary and tertiary economic activities. Peri-urban land use is a transitional area in rural zones with a residential use that is at risk of becoming permanently occupied by urbanisation; and rural land use, which includes zones with purely forestry or agricultural characteristics.

Once the islands of the ORs that have high anthropic pressure characteristics are detected, a monographic analysis of the regional planning strategies is carried out to obtain a holistic view of the level of confluence with the European spatial and urban planning policy and the criteria of adaptation described in the European Urban Agenda of the Pact of Amsterdam (Svedin, 2011; European Commission, 2013).

We have focused, therefore, on the planning tools that cover the entire island territory and allow us to perform a detailed analysis of territorial strategies. This kind of monographic analysis of the case studies allows us to better understand the complexity of the management of insular territories in the face of the new challenges of climate change.

\section{Selection of case studies}

As highlighted before, the analysis focuses on islands that have diverse activity poles, according to the Category 2 defined by Sanguin (2007). To determine the most relevant case studies of the islands of the ORs, we make a comparison of the variables of land use and densities among the islands of similar typology to determine the representative cases of greatest anthropogenic pressure. There are important differences depending on the distance from the continent; thus, we differentiate between those included within continental influence and the ultra-peripheral ones, in accordance with the previously mentioned criterion of the European Union. Related 
to climate change projections, for 2100 , in both cases these islands will be affected by new patterns in temperature, precipitations and sea level rise.

Table 1: Characteristics Sanguin's Category 2 EU Outermost Islands (ORs) and climate change projections for 2100 in comparison to EU island with continental influence.

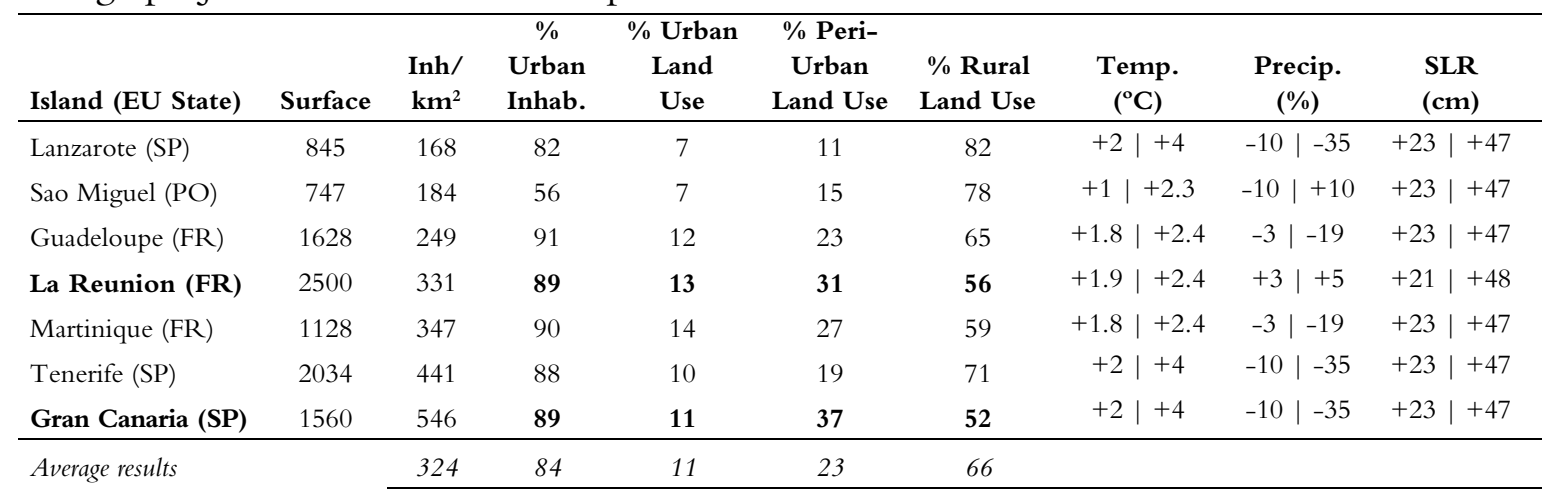

Islands within continental influence:

Average results

$105 \quad 67$

$7 \quad 15$

79

Note: The islands selected within continental influence were: Naxos, Cephalonia, Lesvos, Chios, Crete, Rhodes, Zakynthos and Corfu (GR), Sardinia (IT), Corsica (FR), Minorca, Ibiza and Majorca (SP). Abbreviations: (SP) Spain, (PO) Portugal, (FR) France, (GR) Greece, (IT) Italy. Inh $/ \mathrm{km}^{2}$ (Density in inhabitants per $\mathrm{km}^{2}$ ). Climate Change Projections: Annual Mean Temperature (Temp.), Precipitations (Precip.) and Sea Level Rise (SLR). Sources: Insee (France); INE, Consells, Cabildos, Gobierno de Canarias (Spain), INE (Portugal), ELSTAT (Greece); Istat (Italy), 2016. Climate Projection Data from IPCC (2013).

When observing the land use pattern in both subgroups, we see the importance of the pressure exerted by urban and the peri-urban expansion. Islands closer to the continent, which are within its area of economic influence, have lower average urban land use values than the outermost islands (a difference of 4\%). The dynamics of urban growth in islands of the ORs lead to a reduction of fourteen percent in the exclusively rural areas (agricultural-forestry). While in the first subgroup, rural land use represents on average $79 \%$ of the island territory, in the Outermost Regions this area is only 66\%. The value of non-urban land use is most significant on the islands of Gran Canaria and Reunion, reaching very dangerous levels close to $50 \%$, followed by Martinique with 59\%. The average value of the urban population in each group reveals that the islands of ORs currently exceed the expectations of EU (Eurostat, 2016, p. 9) for 2050. In some islands of this subgroup, the lack of available land raises the percentage of population living in urban areas to nearly $90 \%$ (Table 1).

As shown in Table 1, the average density of the islands within the area of continental influence (situated from $1 \mathrm{~km}$ to $400 \mathrm{~km}$ from the continent) is $105 \mathrm{inhab} / \mathrm{km}^{2}$, while the density in the islands of the ORs is $324 \mathrm{inhab} / \mathrm{km}^{2}$. In the group of the outermost islands, the islands of Martinique and Reunion have greater presence of urban land use than the rest, and the islands of Tenerife and Gran Canaria support the greatest demographic pressure within Europe. In all these islands, the trend follows an urban pattern characterized, as Grydehøj (2015) indicates, by a significant concentration on the coast. 
To contextualise the densities obtained, we have compared these averages with those obtained in similar cases on the continent, selecting the provincial as an optimal comparative scale. For the comparative analysis, we have selected as a study group those Spanish provinces whose capital is situated on the coast. The characteristics of the mainland provinces with coastal capitals have several factors in common with the island territories: generally, the provinces and their capitals concentrate first-order tourist resorts, also providing service infrastructure and transportation in a very similar way to the islands. The Spanish coastal provinces, except for Barcelona, find themselves with lower urban pressures compared to the levels of the islands of the ORs; ten percent less. Setting the territorial density of islands of ORs and analysing the territorial coastal areas of greatest density in continental Europe, only large coastal conurbations surpass the urban and peri-urban land use of the Canary Islands or Reunion Island. We refer to Lisbon, Oporto, Naples, the Region of Attica (Athens) and the Dutch administrative regions of Rotterdam, The Hague and Amsterdam. From the above data, ORs islands have a greater average urban pressure than the most urbanized coastal areas of the continent, both in terms of land use and demographic density values. While the islands with continental influence have similar density patterns to their mainland references, islands of the ORs have greater urban and peri-urban pressure, a determinant factor in the degree of vulnerability to climate change.

From this comparative analysis carried out, the islands of Gran Canaria and Tenerife (Canary Islands, Spain), Martinique and Reunion (France) undergo the highest demographic pressure, but especially Gran Canaria and Reunion Island also have very anthropized land use, the non-urban surface area being of values close to $50 \%$, while in the other outermost islands, non-urban land use (rural land use) is around 60\% or more (Martinique, 59\% , Guadeloupe, 65\% and Tenerife, 71\%). Thus, the monographic analysis of the integration of the adaptation to climate change into planning has focussed on the islands of Gran Canary and Reunion.

\section{Territorial context}

The islands of Gran Canaria and Reunion have similar conditions and characteristics to the outermost regions. The remoteness of the continent, which generates a strong economy of dependence on products and economic sectors mainly related to agriculture and tourism and the complex topography limits the possibilities for growth and expansion; a key factor in the increase in vulnerability to natural risks (volcanology, landslides, loss of biodiversity, etc.) (Lozano, 2006; Le Masson \& Kelman, 2011). Another risk factor is their scarce surface area that, associated with geomorphological conditions, obliges a high concentration of the population, as well as economic activities along the coastline. This common confluence of risks is now increased by the special sensitivity to extreme weather events (floods, droughts, sea level rise, etc.) due to global warming (Nurse et al., 2014).

The island of Gran Canaria had its demographic explosion in the second half of the twentieth century, when from just over 100,000 inhabitants its population multiplied by six. Gran Canaria, therefore, has a very high demographic density, well above the values of continental Spain and the European Union. The extraordinary economic development in the first decade of the $21^{\text {st }}$ century, with an improvement in mobility that facilitated access to basic services, promoted an urban expansion unparalleled in insular history. Although the 
main city, Las Palmas, concentrates almost half the island's population, the shift in economic activity from large-scale agricultural exports towards tourist and commercial development has led to very significant spatial and structural change. The forestry system of Gran Canaria makes up $29 \%$ of the island's surface, while $60 \%$ is a transition space between purely rural areas and dispersed urban zones with a high risk of negative anthropic processes. Finally, the urban system makes up $11 \%$ of the island's surface, incorporating the main urban population settlements and spaces for economic activities, including industrial, tourist and scientifictechnological areas in the island's two main coastal corridors to the north and east (Cabildo de Gran Canaria, 2014; 2017).

Related to the tourist pressure, in Gran Canaria with a GDP (2015) of $€ 19,200$ per capita, the number of visitors in 2017 was 4,075,607 (Cabildo de Gran Canaria, 2018). Las Palmas city and the southern touristic area of the island are foci that attract workers due to their high demand for labourers for the secondary and tertiary sectors. Thus, nowadays the nearby towns are growing, most becoming dormitory towns. Finally, tourist towns are home to a large floating population that impacts on the consumption of resources, a pressure that is clear not only in the spatial distribution, but also over time, as the annual pressure is constant. The spatial tension necessitated the declaration in 2003 of a moratorium to enable better management of the tourist infrastructures that has not provided the expected results (Rodríguez \& Santana, 2012; Simancas \& Ledesma, 2016). In 2017 the new Land Use Act of the Canary Islands cancelled this limitation and a new process of conflict is foreseen. The tourism sector is expected to expand causing urban pressure to increase and, therefore, the current effects of climate change may become exacerbated. Bearing this in mind, the 2017 Land Use Act mentions, for the first time, the importance of considering climate change in the development strategies, however, it does not define specific measures in the regulatory framework.

Reunion Island has had similar behaviour since 1950, in which it had 250,000 inhabitants. Until the year 2000 the population had increased by three times, but unlike Gran Canaria the growth rates are still very high. It is projected that by 2040 the population could increase by $27 \%$ (Levet, 2010). Although there are differences between the case studies, Reunion Island largely follows the spatial pattern of Gran Canaria. The territorial distribution of land uses in Reunion Island is very significant, economic activities are in low altitude areas linked to the communications network and agricultural production centres.

The understanding of altitude and accessibility variables is fundamental when performing any spatial analysis. In both islands, about $80 \%$ of the population is located in coastal areas below the altitude of 400 metres, where communications through roads are much more comfortable. These areas have facilitated the generation of economic activities and, associated with this dynamic, the urban settlements have been proliferating in the less mountainous areas (Figure 2). 


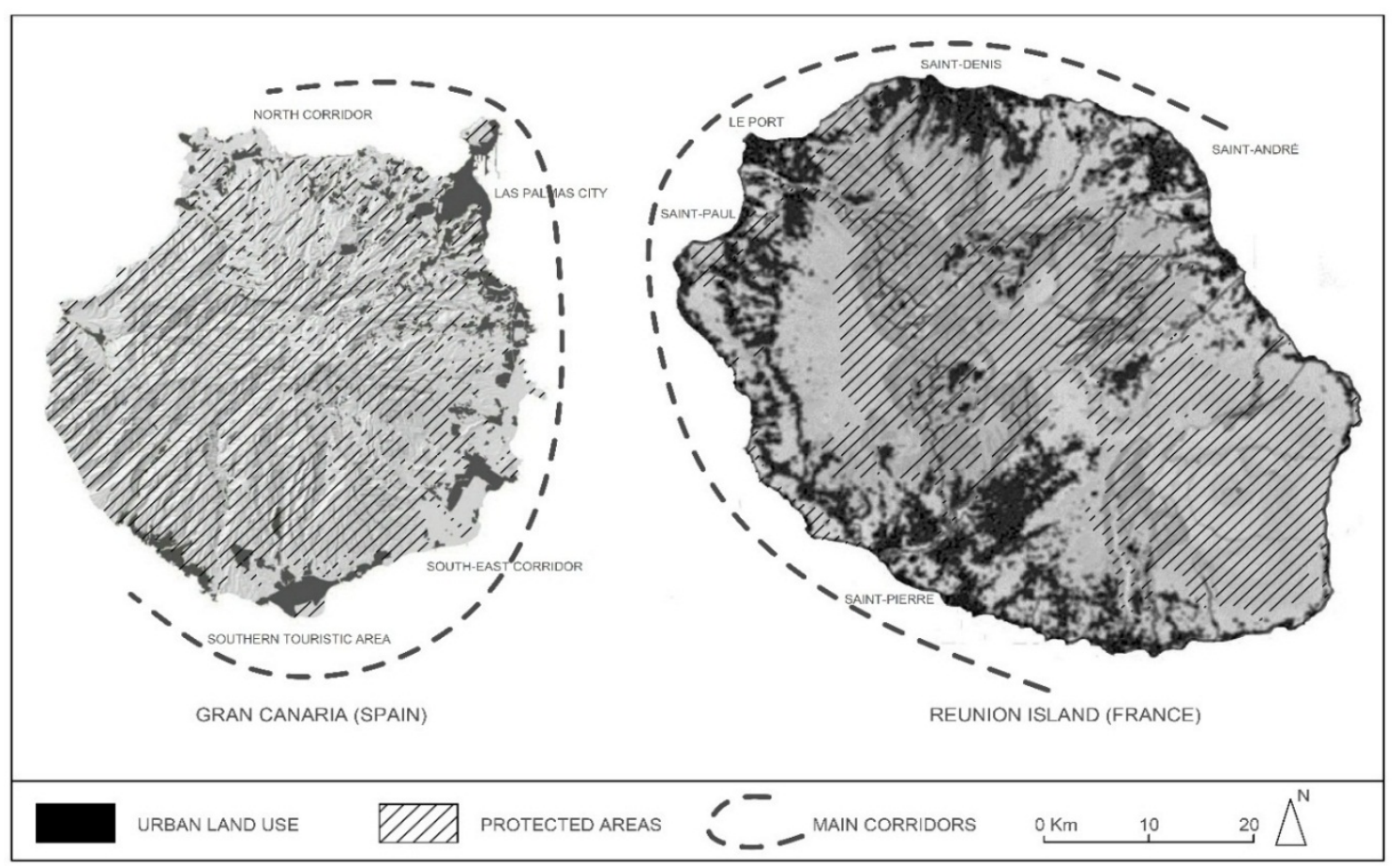

Figure 2: Spatial structure of the islands of Gran Canaria and Reunion. Source: Spatial Planning Tools (PIO-GC and SAR). Compiled by authors.

The arc formed by the coastal road network between Saint-Pierre to the south, the north-western sector of Saint-Paul and Le Port, the island capital Saint-Denis and the conurbation of Saint-André shows the urban explosion of the island in all its dimensions (Jauze, 1998; Agorah, 2014). The loss of ecosystems and biodiversity due to human intervention is remarkable, approaching high risk values (DEAL, 2012, p. 47). A strong policy of environmental protection still allows $56 \%$ of the territory to be maintained free of anthropic action. The traditional rural settlements are gradually transformed into more compact nuclei associated with new dispersed urban growths that occupy abandoned farmland. The eminently rural anthropic space accounts for $32 \%$ of the territory, meanwhile urban land use occupies $12 \%$. The progressive loss of productive capacity of the primary sector gives way to new poles of tertiary activity, where tourism has been acquiring greater relevance since the late 90s (INSEE, 2014; Legros, 2016).

Reunion, with a GDP (2015) of $€ 21,900$ per capita, barely reached 458,261 tourists (IEDOM, 2016, p. 97). In this case, the resorts are located in the western sector of the island in a dispersed and unstructured way, but it is foreseeable that with the improvement of infrastructures, the trend will be similar to the case of the Canary Islands.

To sum up, as we have seen, along with the high level of risk associated with natural causes, the strong occupation of the territory by urban land use and the high demographic and tourist pressure, especially in Gran Canaria, the increase of impacts due to climate change is an added factor that complicates the management of the territory. 


\section{Discussion}

Spatial and urban planning is subject to the environmental and social conditions of a territory. As we have already indicated, climate change becomes part of these conditions and the need for adaptation begins to be urgent. In this sense, islands need to start experimenting with new planning formulas with a clear aim towards sustainability, focusing on the effective mitigation and adaptation to climate change of their communities, beyond their exemplary reference role (Grydehøj \& Kelman, 2017). The use of islands as places of experimentation has been argued by different authors in many fields of study (Depraetere, 2008, Gagliardi, 2009, Kelman et al., 2015), but it is in the discipline of spatial and urban planning, where the use of common tools can advance extrapolatable results to other territories.

National climate change policies already took into consideration the importance of regulating adaptation strategies in spatial and urban planning at the beginning of the new century. In 2006, Spain drafted its National Adaptation Plan which gives a relative importance to planning, considering it as a key sector of the adaptive strategy (Gobierno de España, 2006). However, as the competences for regional planning fall on the Autonomous Communities, there is a disparity of situations related to adaptive strategies in spatial and urban planning (García, 2016). In the specific case of the Canary Islands, the archipelago developed the Canary Islands Strategy against Climate Change (CI-Strategy) ten years ago (Gobierno de Canarias, 2009). The complex economic crisis that Spain has been suffering since 2008 caused the suspension of the CI-Strategy in 2011. The public entities created for its management disappeared between 2011 and 2015 within the framework of the measures adopted by the Canary Islands Government for budget control, a fact that has limited the adaptation policies to climate change in the islands (López et al., 2015). However, this document had not integrated adaptation adequately. The CI-Strategy delegated this aspect to the development of the insular plans, as the only spatial planning tools established by the governments of each island (Cabildos). The Gran Canaria Insular Plan (PIO-GC), with first approval in 2014, and then in 2017, incorporated some criteria related to climate change, but it did not go on to define concrete adaptive actions that empowered municipalities in the face of extreme events associated with this phenomenon (Cabildo de G.C., 2014; 2017). That same year, the Cabildo created the Climate Change Observatory (Observatorio Canario de Cambio Climático), a Climate Action Group within the framework of the Covenant of Mayors, to identify the risks associated with climate change and evaluate the actions needed to reduce greenhouse gas emissions and increase climate adaptation. However, the municipalities of the Canary Islands do not yet have a compulsory regulatory framework that enables the development of a local adaptation strategy.

In this sense, the response of Gran Canaria and its Insular Plan, related to climate change adaptation, does not cover all the desired expectations. The combination of sustainable planning and management for adaptation to climate change is one of the most complex challenges. PIO-GC suffers from a lack of definition of clear adaptation measures, since the risk associated with climate change is not considered as a starting premise in planning strategies. The lack of promotion from the regional and insular government, with legislation lacking commitment to climate change, and the absence of technical will to incorporate adaptation among the strategies of the PIO-GC, leads to a document with inadequate management of climate change. The threat of sea level rise, with processes of coastal erosion 
or marine transgression, is partially considered and only green infrastructure is understood to be an adaptive resource, as an essential element for greater resilience (Table 2).

The lack of definition of the Spanish case has as a counterpoint in the effort of climate change adaptation that has been carried out in France in the last decade. With the approval of the Stratégie Nationale d'Adaptation (ONERC, 2007), French spatial planning has been incorporating adaptation strategies in an increasingly consistent way. However, the French insular ORs are still not the subject of a specific climate action plan (Ferdinand, 2018, p. 125) and need planning tools for its implementation. The outermost French regions, as is the case of Reunion Island, have two essential planning tools for adequate inclusion of adaptation strategies in the management of the territory. The main document for spatial planning is the Schéma d'Aménagement Regional (SAR) approved by the Council of the State in 2011. This instrument, binding for the municipal plans, defines the planning and fundamental guidelines in the medium term for sustainable development, as well as the basic instructions for protection and development on the coast. The integration of climate change is one of the objectives of the SAR, focusing on adaptation as a key aspect (Region Reunion, 2011). The strategy followed is based on the principle of preventive risk management, focusing on the preservation of water and material resources, and approaching energy independence, where land use models are decisive.

The guidelines established by the SAR are specified in the Schéma Régionale Climat, Air, Energie (SRCAE) approved at the end of 2013 in accordance with the 2010 Act, National Commitment to the Environment (Grenelle 2). The objective of this programme is to define the guidelines and objectives of the region for 2020 and 2050 in combatting air pollution, focusing on the development of renewable energies and the reduction of greenhouse gas emissions, but also placing emphasis on climate change adaptation (Region Reunion, 2013). The SRCAE is a strategic document that does not implement individualized actions, however, following the strategies defined in the SAR and in the SRCAE, municipal planning tools will establish the specific actions (Table 2).

The spatial planning of Reunion Island, which predates the approval of the EU Strategy on Adaptation or the Urban Agenda, addresses all these aspects in an advanced way. For instance, one of the issues that the SAR places in the regulatory transition scenario related to climate change adaptation is the establishment of the criterion of "risk control" as a principle in any anthropic intervention. It is, therefore, about avoiding risk in urban environments, reducing the impact on infrastructures. Moreover, this planning tool seeks to favour "comprehensive management" of the risks arising from climate change. This aspect can only be implemented taking into account four fundamental elements: a better knowledge of climate variability, which enables the establishment of a preventive information system; the criterion that any development project must not imply an increase in risk, reducing the level of problems associated with extreme weather events (risk reduction); the establishment of a management scheme for possible climate crises and; the introduction into the planning tools of the protection criterion, limiting, if necessary, the possibilities of urban growth, for this a new spatial planning would be established in order to protect goods and people. In short, the SAR and its management programme SRCAE reflect the impacts of climate change on the development of spatial planning tools. Reunion Island has become an area for experimentation of new planning strategies with the aim of reducing the vulnerability of the population and infrastructures. 
Table 2: Extreme climatic events assumed by the insular spatial planning tools.

\begin{tabular}{ccc}
\hline $\begin{array}{c}\text { Climate Change } \\
\text { Impacts }\end{array}$ & $\begin{array}{c}\text { Gran Canaria Insular Plan } \\
\text { (PIO-GC) }\end{array}$ & $\begin{array}{c}\text { Regional Development } \\
\text { Scheme Reunion Island (SAR) }\end{array}$ \\
\hline Sea level rise & Yes & Yes \\
Storm-surge & No & Yes \\
Coastal regression & Yes & No \\
Floods & Yes & Yes \\
Heat-island effect & No & Yes \\
\hline
\end{tabular}

It must be borne in mind that both PIO-GC and SAR establish different categories of land use according to their specific spatial characteristics. Therefore, areas that do not have permanent protection are the most vulnerable to human pressures. Planning tools should identify those land uses whose functions are essential for ecological services, and reaffirm and complement the protection mechanisms, since most adaptation strategies need them.

Table 3: Adaptation criteria related to Priority Themes of the European Urban Agenda.

Regional Development

Gran Canaria Insular Plan

Scheme Reunion Island

European Urban Agenda

(PIO-GC)

(SAR)

Priority Theme
No. 7. Climate adaptation (including green infrastructure solutions)

Partially -

Partially +

Partially committed to

introducing adaptation strategies Considers the mitigation capacity

(Vol 1 \# 4.4: 82-86 [2014], Vol 1 of green infrastructure but does

\# 2.3.6: 52-53 [2017]). Control not establish any coherent

of risk in accordance with adaptation strategy (\# 5.7: 76; \#

international mitigation 6.4, pp. 207-208). There is no

agreements (Vol 2A \# 5.1: 41; \# study of the retreat of coastline,

6.1: 52 [2014], Vol 3 \# 1.3.3: 8 but sea level rise is contemplated

[2017]). Adaptation criteria in for spatial rearrangement of

coastal management (Vol 4 \# 3.1: urbanized areas (\# 6.11.1.3 a \#

21 [2014], Vol 1 \# 4.3: $219 \quad$ 6.11.1.5, pp. 310-324).

[2017]).
Yes

Specifies a guiding-principle based on the establishment of a hierarchical structure in the territory, validating the principle of space economy (Vol 2A \# 2.3: 24-25[2014], Vol 3 \# 6.5: 222223; Vol 3 \# 3.6: 49 [2017]).
Effectively the maximum limits of urban development in search of an adequate balance between the urbanized and the natural environment are established (\# 12.2.2, pp. 363-364) development of brownfields and on renaturing / greening Urban Areas.

The necessary strategy for correct management of climate change in planning needs adequate containment of urban land use. In this regard, the European Urban Agenda establishes an initial list of Priority Themes where the climate issue is a relevant aspect 
(European Commission, 2016, pp. ii-iv) in actions related to urban land use. According to the Urban Agenda, two key aspects are identified: on the one hand, the control of greenhouse gases marks a clear mitigation policy, in accordance with exclusively energetic considerations (air quality, energy transition and urban mobility (Themes 2, 8 and 10)); on the other hand, climate change adaptation is imposed on the development of planning: Climate adaptation (including green infrastructure solutions) and sustainable use of land and Nature-Based solutions (Themes 7 and 9). Climate adaptation and sustainable land use are part of comprehensive management of urban and peri-urban areas in relation to the territory. Under the umbrella of these Priority Themes, insular planning must take into consideration aspects such as impacts, planning directed towards disaster control, environmental protection, coastal and marine environment management, as well as conflicts arising from the pressure exerted on land use (Table 3).

Comparing the two spatial planning formulas in Gran Canaria and Reunion Island, there are clear similarities in essential aspects such as, for example; trying to contain urban expansion through more restrictive measures in the modification of land uses, previously determining the residential load capacity and economic activities; the control of peri-urban space by recovering vacant lots without activities within urban nuclei, promoting new centralities and; proposing mechanisms of urban regeneration and increasing density to prevent spread and reduce mobility requirements. Planning in both regions has the basic principle of efficient use of the island's territory. Along with this guideline, these planning tools have a set of core objectives (guiding principles) which are coherent with planning challenges in any island or continental territory, but the French case has taken some steps forward in the integration of the climate issue.

However, a subject that remains latent in the two forms of planning is the fact that, understanding that climate change will continue, it is necessary to introduce a component of flexibility in planning. We must avoid a vision of the term flexibility where planning is understood as an element of opportunity for the private sector, especially in a traditional regulatory framework such as the French or Spanish ones, strongly marked by a "plan-led system” (Muñoz \& Tasan-Kok, 2010). It requires, however, a new attitude when establishing planning management strategies whose challenge will be to incorporate climate change. These planning tools are more similar to the direction emphasized by Friedmann (2003) where planning must go from an instrument of control to an instrument of innovation and action.

Thus, we are in a renewed process of changing connotations of flexibility, previously reflected in the literature (Tasan-Kok, 2008, p. 187) but with a new component not yet explored; climate change and the adaptation capacity to new conditions. In the case of Gran Canaria, the term used in the first document of the Insular Plan is "Elasticity" (Cabildo de G.C., 2014, p. 67). Along with criteria of spatial functionality, elasticity in planning enables a wide-range of land use changes to be designed in a more adaptive future. This principle considers that planning does not end in the drafting process but is permanent and applicable at any time since the implementation of the planning could have certain unforeseen defects that can be corrected during the development of the Plan. However, the changes introduced in the last Insular Plan support the territorial flexibility in the face of climate change in the containment of urban growth (Cabildo de G.C., 2017, p. 412). Meanwhile, Reunion Island has a more static vision, calling for greater control (SRCAE, 2013, p. 71) to reconcile flexibly 
the increase in population and limit the energy demand, while guaranteeing preservation of natural and agricultural environments in the context of climate change.

In our analysis we observe a change in motivation in the legislative sector, which proposes the reorganization of the initial planning criteria, legitimized by a greater knowledge of the risk events with more probability of impact. The ability to introduce adaptation strategies into planning tools depends largely on the correct determination of climate change scenarios. Climate change scenarios handle a high degree of uncertainty due to the microclimatic conditions of the islands which can not be introduced in Regional Climate Models (since they can only capture the large-scale athmospheric circulation). In spite of this, spatial and urban planning must assume this uncertainty and incorporate the simulations in its determinations. The insular urban policies must fight to eliminate the barriers to adaptation management as an incipient concept and promote suitable legislation that empowers the municipalities for their correct execution.

On the other hand, with respect to the social dimension of the adaptation (Priority Theme 7), a deficit can be observed in the process of participation of the communities in both islands. The scarcity of specific adaptive actions in the planning shows both the lack of technical integration of the climate issue and also a reduced role of social capital in the decision making. This is basically due to the ignorance among the population of the impact derived from climate change and the scarce budget provision for adaptation of the European Union and the states themselves. The population clearly recognises the need for a transition towards more sustainable land management models, however, the need to relocate uses and activities situated in vulnerable sectors is not accepted. The scarce participation of the population in decision making is being reverted by providing incentives for more participative risk management processes, examples of which are occurring in other European islands such as Tenerife or The Isles of Scilly (Hernández et al., 2018; Petzold, 2018). The decision on adaptation strategies follows a pattern imposed by the administration (top-down), in which community participation has not been adequately promoted.

\section{Conclusion}

Island regions are able to be taken as an example of conflict in the management of climate change. Spatial adaptation to the consequences of climate change is essentially a matter of changes in the configuration of the territory, especially in urban and peri-urban areas. The analysis carried out demonstrates that the ORs of Gran Canaria and Reunion Island have initiated the incorporation of the climate issue into planning tools. Undoubtedly, the special conditions of both islands, both in their relations to climate change as well as the mainstreaming adaptation into planning tools, represent a huge technical and management challenge. The confluence of these aspects is an incentive for the experimentation of new planning strategies incorporating flexibility related to the new environmental conditions derived from climate change. It has been possible to detect that this experimentation is taking place although the advances in the integration of the adaptation are not sufficiently relevant.

An interesting aspect of the planning tools in both territories is the establishment of a balance between sustainable development and territorial efficiency with sufficient flexibility to gradually adapt to the climate changing conditions. In the case of Gran Canaria, the challenge is to incorporate climate change adaptation into its regulatory framework and 
maintain the dynamics of tourism through the development of adaptation measures considering changes in climatic conditions. In Reunion Island, if the population growth forecasts are fulfilled, a critical mass may be reached, justifying a stronger position in the local autonomy of its planning decisions in the face of climate change.

Despite this, the analysis performed on the degree of coincidence of the Priority Themes from the European Urban Agenda with those of the islands themselves has identified some divergences related to the response to the threat of climate change. This aspect has not yet been included in the Spanish framework in a binding way, as proven in Gran Canaria. In contrast, Reunion Island has taken important steps in mainstreaming adaptation into spatial and urban planning, placing itself in an exemplary position.

The capacity of the outermost European regions is very limited in adjusting the planning decisions to the criteria of the European Strategy on Adaptation and the Urban Agenda defined by the Pact of Amsterdam. However, the French model has introduced the climate issues in a direct way as opposed to the planning made in the Canary Islands. These differences have their origin in the regulatory framework because, from a spatial management viewpoint, as non-sovereign islands they are subject to support from their metropolises in accordance with the interests of the continent (Le Masson \& Kelman, 2011). The apparent autonomy of decision in establishing their own planning rules must be followed and supported by both the European institutions and their respective countries.

Therefore, together with the identified limitations, there are two problems that are added in the spatial management of the islands of the ORs. Firstly, an inadequate definition of the legal framework of planning tools that incorporate the issue of adaptation within their normative corpus. As we have indicated, the lack of concreteness of the Spanish National Adaptation Plan has also resulted in a lack of normative specification in the Canary Islands Strategy against Climate Change. Moreover, procrastination in taking adaptation decisions since the adoption of the 2007 French Strategy brings to light management errors and raises the spectre of a "discontinuity" (Region Reunion, 2011, p. 97), in the process of normative integration of Reunion Island. Secondly, in both cases, the scarce participation of social capital in the definition of adaptation strategies is recognized. As for the social dimension, there is a regulatory framework that does not favour the participation of the population in decision making, a top-down structure being imposed.

\section{References}

Agorah (2014). Bilan 2014 des Observatoires del'Agorah. Donnes, tendences, croisements, focus. Agence d'Urbanisme à La Réunion.

Aswani, S., Vaccaro, I., Abernethy, K., Albert, S., \& de Pablo, J.F. (2015). Can perceptions of environmental and climate change in island communities assist in adaptation planning locally? Environmental Management, 56(6), 1487-1501. https://doi.org/10.1007/s00267$\underline{015-0572-3}$

Berrang-Ford, L., Ford, J., \& Paterson, J. (2011). Are we adapting to climate change? Global Environmental Change, 21, 25-33. https://doi.org/10.1016/j.gloenvcha.2010.09.012

Booth, P. (2011). Culture, planning and path dependence: Some reflections on the problems of comparison. The Town Planning Review, 82(1), 13-28. https://doi.org/10.3828/tpr.2011.4 
Cabildo de G.C. (2014). Plan Insular de Ordenación. Las Palmas de Gran Canaria, Islas Canarias. http://planesterritoriales.idegrancanaria.es/PIOGC 2014-12-12 (2014-1128 SRSIP) PIO APINI FIR.xml

Cabildo de G.C. (2017). Plan Insular de Ordenación. Las Palmas de Gran Canaria, Islas Canarias. http://planesterritoriales.idegrancanaria.es/

Cabildo de G.C. (2018). Estadísticas turísticas de Gran Canaria. http://www.grancanaria.com/patronato turismo/Estadisticas.23492.0.html

Chapman, D. (2011). Inside outside: spatial planning and small islands. Centre for Environment and Society Research. Working Paper series no. 7, Birmingham City University.

DEAL (2012). Profil Environnemental de La Réunion. Direction de l'Environnement, de l'Aménagement et du Logement de La Réunion. Saint Denis : Service Connaissance Evaluation et Développement et Durable.

Depraetere, C. (2008). The challenge of Nissology: a global outlook on the world archipelago, part 1: scene setting the world archipelago, Island Studies Journal, 3(1), 3-16.

ESPON (2013). ET2050. Outermost Regions report: territorial scenarios and visions for Europe. https://www.espon.eu/programme/projects/espon-2013/applied-research/et2050-territorialscenarios-and-visions-europe

Etkin, D. (2009). Patterns of risk: spatial planning as a strategy for the mitigation of risk from natural hazards. In U. Fra Paleo (Ed.) Building safer communities: risk governance, spatial planning, and responses to natural hazards (pp. 44-60). Amsterdam, Netherlands: IOS Press. https://doi.org/10.3233/978-1-60750-046-9-44

European Commission (2016). Urban agenda for the EU, pact of Amsterdam. Amsterdam: ESPON.

European Commission (2014a). The urban dimension of EU policies: key features of an EU urban agenda. Brussels 18.7.2014; $\operatorname{COM}(2014) .490$.

European Commission (2014b). The economic impact of climate change and adaptation in the Outermost Regions: final report. Directorate-General for Regional and Urban policy. Luxembourg: European Commission.

European Commission, (2013). Communication from the Commission to the European Parliament, the Council, the European Economic and Social Committee and the Committee of the Regions. An EU strategy on adaptation to climate change. Brussels, 16.4.2013. COM(2013) 216.

European Commission (2009). The economics of climate change adaptation in EU coastal areas. European Commission, Directorate-General for Maritime Affairs and Fisheries.

European Union (2014). Cities of tomorrow: annex. Directorate General for Regional Policy. Brussels: European Commission.

European Union (2011). Cities of tomorrow. challenges, visions, ways forward. Directorate General for Regional Policy. Brussels: European Commission.

Eurostat (2016). Urban Europe, statistics on cities, towns and suburbs. Luxembourg: Publications office of the European Union. https://doi.org/10.2785/91120

Ferdinand, M. (2018). Subnational climate justice for the French Outre-mer: postcolonial politics and geography of an epistemic shift. Island Studies Journal, 13(1), 119-134. https://doi.org/10.24043/isj.49

Friedmann, J. (2003). Why do planning theory? Planning Theory, 2(1), 7-10. 
Füssel, H.M. (2007). Adaptation planning for climate change: concepts, assessment approaches, and key lessons. Sustainability Science, 2, 265-275. https://doi.org/10.1007/s11625-007-0032-y

Gagliardi, P. (2009). Organisations as designed islands. Island Studies Journal, 4(1), 43-52.

Gagliardi, L. \& Percoco, M. (2017) The impact of European Cohesion Policy in urban and rural regions, Regional Studies, 51:6, 857-868. https://doi.org/10.1080/00343404.2016.1179384

Garcia, C., \& Servera, J. (2003). Impacts of tourism development on water demand and beach degradation on the island of Mallorca (Spain). Geografiska Annaler, 85(A.3-4), 287-300.

García, F. (2016). Patrimonio, regeneración urbana y adaptación al cambio climático: Un estudio de casos en Cantabria, España. Sixth Rehabend Euro-American Congress, Construction Pathology, Rehabilitation Technology and Heritage Management. May 2016, Burgos.

Gobierno de Canarias (2009). Estrategia Canaria de Lucha contra el Cambio Climático. Agencia Canaria de Desarrollo Sostenible y Cambio Climático. Gobierno de Canarias.

Grydehøj, A. (2015). Island city formation and urban island studies. Area, 47(4), 429-435. https://doi.org/10.1111/area.12207

Grydehøj A., \& Kelman, I. (2017). The eco-island trap: climate change mitigation and conspicuous sustainability. Area, 49(1), 106-113. https://doi.org/10.1111/area.12300

Hantrais, L. (2008). International comparative research: theory, methods and practice. London: Macmillan Education.

Hay, P. (2006). A phenomenology of islands, Island Studies Journal, 1(1), 19-42.

Hernández, Y., Guimarães, Â., \& Barbosa, P. (2018). Resilient futures of a small island: a participatory approach in Tenerife (Canary Islands) to address climate change. $\begin{array}{lllll}\text { Environmental Science } \& \text { Policy, } & \text { 80(February), }\end{array}$ https://doi.org/10.1016/j.envsci.2017.11.008

IADB (2016). Guía Metodológica Programa de Ciudades Emergentes y Sostenibles: Tercera edición: Anexo de indicadores. InterAmerican Development Bank. $3^{\text {rd }}$ ed.

IEDOM (2017). La Réunion. Rapport annuel 2016. Paris : Institut d'Emission des Départements d'Outre-Mer.

INSEE (2014). Tableau Économique de La Réunion. Institut national de la statistique et des études économiques. Direction Régionale La Réunion-Mayotte. https://www.insee.fr/fr/statistiques/2045700

IPCC (2013). Climate Change 2013: The Physical Science Basis. Contribution of Working Group I to the Fifth Assessment Report of the Intergovernmental. Panel on Climate Change [Stocker, T.F., D. Qin, G.-K. Plattner, M. Tignor, S.K. Allen, J. Boschung, A. Nauels, Y. Xia, V. Bex and P.M. Midgley (eds.)]. Cambridge \& New York: Cambridge University Press.

Jauze, J.M. (1998). L'urbanisation de l'île de la Réunion: évolution et modèles de villes. Cahiers de géographie du Québec, 42(116), 195-221. https://doi.org/10.7202/022737ar

Julien, P. (2000). Mesurer un univers urbain en expansion, Economie et Statistique, 336, 3-33. https://doi.org/10.3406/estat.2000.7508

Kelman, I., Burns, T.R., \& Machado, N. (2015). Islander innovation: a research and action agenda on local responses to global issues. Journal of Marine and Island Cultures, 4, 34-41. http://dx.doi.org/10.1016/j.imic.2015.04.001

King, R. (2009). Geography, islands and migration. Island Studies Journal, 4(1), 53-84. 
Laissy, A. (Ed.) (2011). Growth factors in the Outermost Regions: executive summary. Regional Policy DG, Coordination of Outermost Regions Unit. Brussels: European Commission.

Lazrus, H. (2012). Sea change: island communities and climate change. Annual Review of Anthropology, 41, 285-301. https://doi.org/10.1146/annurev-anthro-092611-145730

Le-Masson, V., \& Kelman, I. (2011). Disaster risk reduction on non-sovereign islands: La Réunion and Mayotte, France. Natural Hazards, 56(1), 251-273. https://doi.org/10.1007/s11069-010-9566-x

Legros, F. (2016). Fréquentation touristique 2015. La fréquentation touristique repart à la hausse. INSEE Analyses Réunion, 16(May). https://www.insee.fr/fr/statistiques/2019610

Levet, A. (2010). Horizon 2040 - La croissance de la population ralentit et le vieillissement s'accélère. INSEE. Informations Rapides Réunion, 167(Decembre).

López, A., Dorta, P., Febles, M. \& Díaz, J. (2016). Los Procesos de Adaptación al Cambio Climático en Espacios Insulares: El Caso de Canarias. X Congreso Internacional AEC: Clima, sociedad, riesgos y ordenación del territorio. September. https://dx.doi.org/10.14198/XCongresoAECAlicante2016-50

Lörincz, A. (2011). The importance of the Outermost Regions for strengthening EU foreign and regional relations. Conference paper at International Conference on The EU as a Global Actor - From the Inside Out: The Internal Development of the European Union and its Future Role in an Interdependent World (Berlin, July $7^{\text {th }}-10^{\text {th }}, 2011$ ).

Lozano, M.A. (2006). Riesgos catastróficos en las Islas Canarias. Una visión geográfica. Anales de Geografía, 26, 167-194.

Mastrandrea, M.D., Heller, N.E., Root T.L., \& Schneider, S.H. (2010). Bridging the gap: linking climate-impacts research with adaptation planning and management. Climatic Change 100, 87-101. https://doi.org/10.1007/s10584-010-9827-4

Moncada, S., Camilleri, M., Formosa, S., \& Galea, R. (2009). Islands at the periphery: integrating the challenges of island sustainability into European policy. Occasional Papers on Islands and Small States 1/2009. Islands and Small States Institute, University of Malta.

Muñoz, D., \& Tasan-Kok, T. (2010). Flexibility in Planning and the consequences for publicvalue capturing in UK, Spain and the Netherlands. European Planning Studies, 18(7), 1097-1131. https://doi.org/10.1080/09654311003744191

Nabielek K., Hamers, D., \& Evers, D. (2016). Cities in Europe. PBL Netherlands. The Hague: Environmental Assessment Agency.

Needham, M., \& Szuster, B. (2011). Situational influences on normative evaluations of coastal tourism and recreation management strategies in Hawai'i. Tourism Management, 32, 732740

Nurse, L., McLean, R.F, Agard, J., Briguglio, L., Duvat-Magnan, V., Pelesikoti, N., Tompkins, E., \& Webb, A. (2014) Small islands. In V.R. Barros, C.B. Field, D.J. Dokken, M.D. Mastrandrea, K.J. Mach, T.E. Bilir, M. Chatterjee, K.L. Ebi, Y.O. Estrada, R.C. Genova, B. Girma, E.S. Kissel, A.N. Levy, S. MacCracken, P.R. Mastrandrea, \& L.L. White (Eds), Climate Change 2014: Impacts, Adaptation, and Vulnerability. Part B: Regional Aspects. Contribution of Working Group II to the Fifth Assessment Report of the Intergovernmental Panel on Climate Change (pp. 1613-1654). New York: Cambridge University Press. 
ONERC (2007). Stratégie nationale d'adaptation au changement climatique. Observatoire National sur les Effets du Réchauffement Climatique. Paris: La Documentation française.

Petit, J., \& Prudent, G. (Dir.) (2010). Changement climatique et biodiversité dans l'outremer européen. Brussels: UICN.

Petzold, J. (2018). Social adaptability in ecotones: sea-level rise and climate change adaptation in Flushing and the Isles of Scilly, UK. Island Studies Journal, 13(1), 101-118. https://doi.org/10.24043/isj.17

Region Reunion (2013). Schéma Régionale Climat, Air, Energie (SRCAE). Conseil Régional de La Réunion. Préfet de la Région Réunion. ADEME). Saint Denis: Conseil Régional de La Réunion.

Region Reunion (2011). Schéma d'Aménagement Régional (SAR). Saint Denis: Conseil Régional de La Réunion.

Region Reunion (2014). Islands declaration on climate change: Reunion Island, 25 June. International climate-energy conference 'Islands and climate change: opportunities, resilience, adaptation', 24-26 June.

Rodríguez, P., \& Santana, M. (2012). Los agentes sociales y la política urbanístico-turística: percepción y performatividad. El caso de las Directrices de Ordenación del Territorio y del Turismo de Canarias. Investigaciones Turísticas, 3, 56-82. https://doi.org/10.14198/inturi2012.3.04

Sanguin, A-L. (2007). Périphéricité et ultrapériphéricité insulaires dans l'Union européenne. L'Espace Politique, 2. https://doi.org/10.4000/espacepolitique.857

Simancas, M., \& Ledesma, O. (2016). La planificación territorial de la política de renovación de las áreas turísticas maduras. Planes de Renovación, Mejora e Incremento de la Competitividad de Canarias. PASOS, Revista de Turismo y Patrimonio Cultural, 14(2), 335352

Sauter, R., ten Brink, P., Withana, S., Mazza, L., Pondichie, F., Lopes, A., Clinton, J., \& Bego, K. (2013). Five case studies on the impacts of climate change on European islands, Annex II to the final report 'Impacts of climate change on all European islands'. Brussels: Institute for European Environmental Policy (IEEP) for the Greens/EFA of the European Parliament.

Smit, B., \& Wandel, J. (2006). Adaptation, adaptive capacity and vulnerability. Global Environmental Change, 16(3), 282-292. https://doi.org/10.1016/j.gloenvcha.2006.03.008

Solbes, P. (2011). Europe's Outermost Regions and the Single Market: the EU's influence in the world. Brussels: European Commission.

Svedin, U. (2011). Urban development and the environmental challenges: 'green' systems considerations. Brussels: Directorate General for Regional Policy, European Commission.

Tasan-Kok, T. (2008). Changing interpretations of 'flexibility' in the planning literature: from opportunism to creativity? International Planning Studies, 13(3), 183-195. https://doi.org/10.1080/13563470802521382

Tompkins, E.L., Adger, W.N., Boyd, E., Nicholson-Cole, S., Weatherhead K., \& Arnell, N. (2010). Observed adaptation to climate change: UK evidence of transition to a welladapting society. Global Environmental Change, 20, 627-635, https://doi.org/10.1016/j.gloenvcha.2010.05.001

UN-Habitat (2014). Planning for climate change: a strategic, values-based approach for urban planners. United Nations Human Settlements Programme. 
Vogel, C., Moser, S.C., Kasperson, R.E., \& Dabelko, G.D. (2007). Linking vulnerability, adaptation, and resilience science to practice: pathways, players, and partnerships. Global Environmental Change, 17(3), 349-364. https://doi.org/10.1016/j.gloenvcha.2007.05.002

Warrington, E., \& Milne, D. (2007). Island governance. In G. Baldacchino (Ed.) A world of islands: an island studies reader (pp. 379-427). Charlottetown \& Luqa: Institute of Island Studies, University of Prince Edward Island \& Agenda Academic.

While, A., \& Whitehead, M. (2013). Cities, urbanisation and climate change. Urban Studies, 50(7), 1325-1331. https://doi.org/10.1177/0042098013480963 